\title{
DISCUSSION
}

\section{ON THE PERFORMANCE GAPS BETWEEN FAMILY AND NON-FAMILY FIRMS IN THE CZECH REPUBLIC}

Family firms form a substantial part of world economics, representing one third of all companies listed on the S\&P 500. In some countries, family firms are becoming the prevalent form of business. One question which necessarily arises is whether they perform better than non-family firms and why. Much academic attention has been devoted to this subject, with mixed results.

\section{The Current State-of-the-art}

Family firms are considered to be different from nonfamily firms because they are owned or managed by members of a family whose intention is to continue the business across generations. Family members are supposed to be altruistic toward each other, following moral obligations which are part of a normative order in most cultures around the world. Recently, we addressed the question of what is the current state-of-the-art in the research on the relation between family involvement and firms' performance. We studied 78 past studies and using a meta-analysis method, we found evidence of a positive relationship between family involvement and businesses performance. We also examined the most frequently used measures of business performance. The most frequently used metric was return on assets (ROA), followed by Tobin's q and sales growth.

Measuring performance gaps between family and nonfamily firms is extremely difficult. One of the main reasons for this is the fact that the definition of family business is not standardized. In the literature, we may find various definitions. We may cite some of the most frequently used ones. Family businesses may be:

- Companies in which majority ownership or control is carried out by a single family and in which two or more family members are directly involved in the business.

- Companies in which family members own at least 50 percent of the business.
- Companies in which a family controls $20 \%$ or more of the voting rights.

- Companies in which family members are officers or directors, or own $5 \%$ or more of the firm's equity.

We suggest that since the definitions of family businesses vary, most studies on performance gaps between family and non-family businesses will differ in the data sample definition, which is likely to have a fundamental impact on the results.

\section{Family Businesses in the Czech Republic}

In the Czech Republic, the issue of family businesses has been ignored for a long time. The distinction of family and non-family businesses is extremely difficult, especially for two reasons:

- Czech companies have no legal obligation to disclose whether they are family firms or not. Such data are not available in any publicly accessible databases.

- It may be difficult to trace the real physical owner if the ownership is realized through multiple legal persons.

In order to collect data on Czech family firms, we used the database Magnus (maintained by the Bisnode company) which contains complex information about Czech economic subjects. From the available data, we had to filter out firms which can be classified as family firms.

To distinguish family firms from non-family firms, we decided to use the family name criterion. A company has been marked as a family firm if there were multiple persons of the identical family name among the managers, owners, or executive boards.

During the filtration process, we took into consideration that in the Czech Republic, female family names usually end in -ová. Only firms with more than 10 employees and total turnover greater than 30 million CZK have been included in the sample. The resulting data set contains 
5709 family firms. However, it is necessary to stress the possible bias due to the data filtration method: on one hand, there may be firms which are actually non-family firms in the sample (due to a possible namesake within the firms), and on the other hand, some family firms may not be included in the sample (for instance, if the spouse decided to maintain her name after marriage). Hundreds of firms will have to be reviewed manually in order to refine the sample.

\section{What Issues Should we Focus on in the Future?}

Since the question of family business has been ignored in the Czech Republic, there is no database of family firms. Our sample of firms is among the first ones. The first step will be to eliminate non-family firms from the large sample of firms we obtained. Then, we will have to choose the right measure of performance. As we already noted, most past studies focused on indicators such as return on assets or Tobin's q. However, the true "family effect" is not necessarily incorporated within classical financial indicators. More interesting outcomes could arise if a measure which takes into consideration the cost of equity was used. The economic value added (EVA) is an example of such indicators. By taking into account the cost of equity, we could examine more accurately the performance differences between family and non-family businesses.

\section{Authors}

Ondřej Machek, Ph.D. Faculty of Business Administration, University of Economics, Prague

Nám. W. Churchilla 4, 13067 Praha 3, Czech Republic ondrej.machek@vse.cz

Assoc. Prof. Jiří Hnilica, Ph.D. Faculty of Business Administration, University of Economics, Prague Nám. W. Churchilla 4, 13067 Praha 3, Czech Republic hnilica@vse.cz

The research on Czech family businesses is being supported by the Internal Grant Agency of the University of Economics in. Prague, project no. F3/9/2013 "Family businesses in the Czech Republic and their performance". 